\title{
Philanthropic Discourse vs Promotional Genre: To Study the Rhetorical Choices of Promotion and Structural Moves of Two Appeal Letters in Hong Kong
}

\author{
Patrick Chi-wai LEE (Corresponding author) \\ School of Humanities and Languages, Caritas Institute of Higher Education \\ 18 Chui Ling Road, Tseung Kwan O, N.T. Hong Kong \\ E-mail: cwlee@cihe.edu.hk
}

Received: 09-03-2016

Published: 01-09-2016
Accepted: $30-05-2016$

doi:10.7575/aiac.ijalel.v.5n.5p.15
Advance Access Published: July 2016

URL: http://dx.doi.org/10.7575/aiac.ijalel.v.5n.5p.15

\begin{abstract}
Based on two appeal letters from (i) Oxfam Hong Kong and (ii) Hong Kong Committee For United Nations Children's Fund (UNICEF), this paper aims to study the rhetorical choices of promotion and structural moves of two appeal letters, exploring whether the philanthropic discourse can be viewed in line with the promotional genre. The findings appear to reveal that there is a hybrid form of promotional genre in philanthropic discourse, with reference to Bhatia's (1998) generic patterns in fund-raising discourse framework. There are similar structural moves of advertising, although the move sequences could vary. However, the move of "introducing the cause" is always found at the very beginning because the readers are more interested to realise what the main theme of the appeal letter is. In addition, appeal letters are found to be modelled in promotional genre, in which they are rhetorical choices of promotion attracting attention from readers - by using "you" and marked devices of attention getters. The findings in this study appear to be in line with the argument that promotional concerns have influenced the nature of philanthropic discourse.
\end{abstract}

Keywords: appeal letters, Hong Kong, promotional genre, rhetorical choices of promotion

\section{Introduction}

This paper aims to examine two appeal letters collected from two international fund-raising non-profit organisations in Hong Kong: (i) Oxfam Hong Kong and (ii) Hong Kong Committee For United Nations Children's Fund (UNICEF). Their purpose of writing is to promote the cause of charity, that is, to persuade an audience of Hong Kong residents to donate money for war victims, and for the education of children. The choice of these appeal letters is motivated by an interest in this type of writing which does not promote goods or services, but charity. The audience is not asked to purchase a commodity but to give away money for something which they cannot redeem personally. The question arises how this type of writing can be viewed in line with other types of promotional writing, especially, whether there is some particular genre after which the appeal letters are modeled. The research objectives in this paper aim to study the rhetorical choices of promotion and structural moves of two appeal letters, exploring whether the philanthropic discourse can be viewed in line with the promotional genre. The significance of this study is to shed light on understanding whether promotional concerns have influenced the nature of philanthropic discourse.

\section{Promotional Genre vs Fund-raising Text}

The prime example of promotional genre is advertising. Advertisements are all around us. Featherstone (2007) rightly claims that we are living in a "consumer culture", where many of our discursive activities, whether in business or academic, or even in personal context, have to some extent been influenced by promotional concerns. The inevitable result of this is that many of the institutionalized genres, whether they are social, professional or academic, are seen as incorporating elements of promotion. In addition, Fairclough (1993:141) points out, “... there is an extensive restructuring of boundaries between orders of discourse and between discursive practices; for example, the genre of consumer advertising has been colonizing professional and public service orders of discourse on a massive scale, generating many new hybrid partly promotional genres...".

Among other research studies, Rotzoll et al. (1986), Kotler, P. and Armstrong (2014) and Wharton (2015) discuss the basic functions of advertising (product or service) and identify two primary roles: to inform and to persuade, and an effective advertising links the wants and needs of the consumer with the properties and functions of the product. The same persuasive purpose is common to a variety of advertisements, promoting a certain kind of products or services. According to Weinstein (2009), fund-raising texts share with these diverse advertisements this one feature, the persuasive function. They persuade readers to donate for charity. More specifically, Clarke and Norton (1997: 21) state that "a fundraising text is more about "selling" than "telling" and it is about persuading people to give". In the previous studies, different linguists may use different approaches for conducting an analysis of the same fund-raising letter. Let me cite as an example and a case in point the eleven contributions in Mann and Thompson (1992). Eleven linguists used 
eleven different approaches to analyse one and the same fund-raising letter. The differences of approach resulted from different degrees of detailing of clause relations, and of degrees of focus on either genre or register. The authors tried to do justice to a "diversity of language functions" (Mann and Thompson 1992: 2). From seeing eleven different analyses at work for one and the same text, it is clear that "there is no consensus on what the relevant set of function is" (Mann and Thompson 1992: 1). However, Bhatia $(1998 ; 2004 ; 2008 ; 2010)$ has pointed out that like most promotional letters in business contexts, fund raising letters also have a relatively simple move discourse structure. Promotional concerns have influenced the nature of entire range of professional and even academic discourse. In Bhatia (1997), he introduces a further dimension to this debate about hybridization; he (1998) also makes an analysis of genre appropriation and mixing on "generic patterns in funding raising discourse", with the aims to investigate the influence of present-day corporate advertising and marketing strategies on the development of philanthropic discourse. Bhatia (1998: 14) highlights the generic patterns in funding raising discourse, listing the similarities and differences in advertising and philanthropic discourse (see table 1).

Table 1. Summary of Similarities and Differences in Advertising and Philanthropic Discourse

\begin{tabular}{|c|c|c|}
\hline ADVERTISING DISCOURSE: & & PHILANTHROPIC DISCOURSE: \\
\hline $\begin{array}{l}\text { ESTABLISHING CREDENTIALS } \\
\text { (By individual needs) } \\
\text { (By long established services) } \\
\text { (By gratitude for past support) } \\
\text { (By celebrity endorsement) }\end{array}$ & {$[1]$} & $\begin{array}{l}\text { ESTABLISHING CREDENTIALS } \\
\text { (By community needs) } \\
\text { (By established cause) } \\
\text { (By gratitude for past support) } \\
\text { (By celebrity endorsement) } \\
\text { (By mission statement) } \\
\text { (By credentials of trustees) }\end{array}$ \\
\hline INTRODUCING THE OFFER & {$[2]$} & INTRODUCING THE CAUSE \\
\hline $\begin{array}{l}\text { OFFERING INCENTIVES } \\
\text { (Special offers discounts) }\end{array}$ & [3] & $\begin{array}{l}\text { OFFERING INCENTIVES } \\
\text { (Income tax rebates) }\end{array}$ \\
\hline $\begin{array}{l}\text { ENCLOSING BROCHURES } \\
\text { (Details of offer) } \\
\text { (Request / order forms) }\end{array}$ & {$[4]$} & $\begin{array}{l}\text { ENCLOSING BROCHURES } \\
\text { (Brochures and mission statements) } \\
\text { (Pledge or donation form) }\end{array}$ \\
\hline SOLICITING RESPONSE & {$[5]$} & SOLICITING SUPPORT \\
\hline USING PRESSURE TACTICS & {$[6]$} & \\
\hline ENDING POLITELY & [7] & EXPRESSING GRATITUDE \\
\hline
\end{tabular}

His finding is to highlight the notion of appropriation of rhetorical strategies across closely related genres. In the case of philanthropic discourse, it is interesting to see that in a number of respects it appears to be very similar to much of corporate promotional discourse, especially when seen in the context of an increasing liberal attitude towards appropriation of generic resources from a much more powerful and hence dominant corporate promotional discourse.

\section{Methodology}

\subsection{The collection of the texts under study}

The process of studying more than thirty, ending up with two appeal letters: those two texts are arrived at by two international non-profit making organisations in Hong Kong. Those two appeal letters are standardized presentation and they appear to be most representative, as checked from the text makers from those two international non-profit making organisations, UNICEF and OXFAM.

\subsection{Format of analysis: Segmentation within text, function and explanation}

Two sample texts are studied and each sample text is divided into single units -segments (seg.), and the segmentation is intended to be a superficial, simple reflection of visible subdivisions (most often sentences, but not all the time). With reference to the textual analysis of all those "segments", this study is to analyse how the words and syntactic structure create effects as the text is read. The function of each segment is reviewed and the rhetorical purpose of each segment in the text is explained. Segments, functions and explanations are related in columns. How different types of segments are treated as exemplified below (Segs. 1-4)

Seg. 1

TEXT

FUNCTION:

EXPLANATION:
Dear Reader,

Salutation

Crucial to the reality of a letter, personal touch with the reader 


\section{Seg. 2}

TEXT

\section{A little help from our donors has repaired 380 school buildings this year}

FUNCTION:

Value the support

EXPLANATION: $\quad$ Solution is quoted as evidence of showing readers the use of resource

\section{Seg. 3}

TEXT

FUNCTION:

EXPLANATION:

segments)

Seg. 4

TEXT

FUNCTION:

EXPLANATION:

\section{Dear Reader,}

Can you stop reading and think about something else?

Relational Opening

Relational open (between "Dear Reader" and "you" in those two

\subsection{Explanation of full analysis in table form}

The following tables 2 and 3 list the findings of the genre mixing of promotional type and philanthropic discourse (based on the sample texts 1 and 2):

Table 2. Full Analysis of an Appeal Letter from UNICEF - Sample Text 1

\begin{tabular}{|c|c|c|c|}
\hline Segment & TEXT & FUNCTION & EXPLANATION \\
\hline Seg. 1 & May xxxx & Date & $\begin{array}{l}\text { - Date is crucial to the reality of the } \\
\text { letter. }\end{array}$ \\
\hline Seg. 2 & Dear Reader, & Salutation & $\begin{array}{l}\text { - } \quad \text { Crucial to the reality of a letter } \\
\text { - } \quad \text { Personal touch with the reader }\end{array}$ \\
\hline Seg. 3 & $\begin{array}{l}\text { Can you stop reading and think } \\
\text { about something else? }\end{array}$ & \multirow{2}{*}{$\begin{array}{l}\text { Segment } 4 \mathrm{~b} \text { is an } \\
\text { attention-getter } \\
\text { (GIMMICK- } \\
\text { Marked device) }\end{array}$} & $\begin{array}{l}\text { - Relational open (between "Dear } \\
\text { Reader" and "you" in segment } 2 \\
\text { and 3) }\end{array}$ \\
\hline Seg. 4 & $\begin{array}{l}\text { (a)This is a letter about children } \\
\text { in war, (b)so stop reading and } \\
\text { switch your attention to } \\
\text { something more pleasurable, } \\
\text { such as what you'll have for } \\
\text { dinner, or what's on the } \\
\text { television tonight. }\end{array}$ & & $\begin{array}{l}\text { - Segment } 4 \mathrm{~b} \text { attracts readers' } \\
\text { attention } \\
\text { (by stimulating readers' curiosity to } \\
\text { read more about this letter) }\end{array}$ \\
\hline Seg. 5 & $\begin{array}{l}\text { Life would be far too stressful if } \\
\text { we couldn't screen out } \\
\text { information that makes us } \\
\text { uncomfortable. }\end{array}$ & \multirow[t]{2}{*}{$\begin{array}{l}\text { INTRODUCING } \\
\text { THE CAUSE }\end{array}$} & $\begin{array}{l}\text { - Segment } 6 \text { is an example to } \\
\text { illustrate the situation of segment } 5\end{array}$ \\
\hline Seg. 6 & $\begin{array}{l}\text { Like, for example, the fact that } \\
\text { over } 50,000 \text { children are still } \\
\text { suffering from the effects of war } \\
\text { in Kosovo. }\end{array}$ & & $\begin{array}{l}\text { - "suffering" is a lexical signal for } \\
\text { the negative evaluation of the } \\
\text { situation as a problem. }\end{array}$ \\
\hline Seg. 7 & Are you still with me? & \multirow{3}{*}{$\begin{array}{l}\text { GIMMICK- } \\
\text { marked device } \\
\text { Attention- } \\
\text { maintaining } \\
\text { device }\end{array}$} & \multirow{3}{*}{$\begin{array}{l}\text { - Cohere with segment } 4 \text { : attention } \\
\text { getter } \\
\text { - "Speech act - Conversation } \\
\text { approach" is shown between } \\
\text { segments } 7 \text { and } 8 \text {. }\end{array}$} \\
\hline Seg. 8 & $\begin{array}{l}\text { Good, because statistically } \\
\text { speaking about } 30 \% \text { of readers } \\
\text { normally would have stopped by } \\
\text { the time they read that fact. }\end{array}$ & & \\
\hline Seg. 9 & $\begin{array}{l}\text { And if you have made it this far, } \\
\text { you are probably ready for } \\
\text { another one: }\end{array}$ & & \\
\hline Seg. 10 & $\begin{array}{l}\text { It's been a year since the NATO } \\
\text { bombings. }\end{array}$ & \multirow[t]{2}{*}{$\begin{array}{l}\text { INTRODUCING } \\
\text { THE CAUSE }\end{array}$} & \multirow{2}{*}{$\begin{array}{l}\text { - "However" is a word showing the } \\
\text { "contrast-relation" between } \\
\text { situation stated in segments } 9 \text { and } \\
10 \text {. }\end{array}$} \\
\hline Seg. 11 & $\begin{array}{l}\text { However, for many children, } \\
\text { life after the war is even worse } \\
\text { than during the conflict. }\end{array}$ & & \\
\hline
\end{tabular}


Seg. 12 Ula, an ethnic Albanian adolescent in Pristina, will be reading a letter from her brother just as you read this one.

Seg. 13 Reading helps her escape from the confines of her bed.

Seg. 14 Ula lost both legs in a landmine accident after the end of the bombing in Yugoslavia.

Seg. 15 She knows her brother's letter by heart, since there is little else to read at the refugee camp.

Seg. 16 She has yet to summon up the courage to tell her brother about her own life.

Seg. 17 She would like to forget about her own misery.

Seg. 18 Victims like Ula need help.

Seg. 19 Help from UNICEF means she will be one of hundreds of children to be reunited with their families.

Seg. 20 A little help from our donors has repaired 380 school buildings this year.

Seg. 21 That little help has delivered 60 metric tonnes of medical supplies.

Seg. 22 The same help has provided counseling to hundreds of child casualties of landmine accidents.

\begin{tabular}{|c|c|c|c|}
\hline Seg. 23 & $\begin{array}{l}\text { In fact, with the enclosed } \\
\text { donor's form, helping out is } \\
\text { almost as easy as it is to stop } \\
\text { reading this letter. }\end{array}$ & $\begin{array}{l}\text { ENCLOSING } \\
\text { DONATION } \\
\text { FORM }\end{array}$ & - $\quad$ Enclosed donor's form \\
\hline Seg. 24 & $\begin{array}{l}\text { You've come this far, all we ask } \\
\text { of you now is to put aside a } \\
\text { minute to fill in the donation } \\
\text { form and change the life of a } \\
\text { child. }\end{array}$ & $\begin{array}{l}\text { Soliciting } \\
\text { RESPONSE from } \\
\text { readers to the } \\
\text { charity } \\
\text { RESPONSE to the } \\
\text { problem by the } \\
\text { charity }\end{array}$ & $\begin{array}{l}\text { - Fill in the donation form } \\
\text { - } \quad \text { Change the life of a child. }\end{array}$ \\
\hline Seg. 25 & Yours sincerely & $\begin{array}{l}\text { Complimentary } \\
\text { Close }\end{array}$ & - Crucial to the reality of the letter \\
\hline Seg. 26 & (handwritten signature) & Signature & \\
\hline Seg. 27 & Dr. Robert H. P. Fung & $\begin{array}{l}\text { ESTABLISHING } \\
\text { CREDENTIAL }\end{array}$ & \\
\hline Seg. 28 & Chairman & $\begin{array}{l}\text { Position (in the } \\
\text { organisation) }\end{array}$ & \\
\hline Seg. 29 & $\begin{array}{l}\text { Hong Kong Committee For } \\
\text { UNICEF } \\
\text { United Nations Children's Fund }\end{array}$ & $\begin{array}{l}\text { ESTABLISHING } \\
\text { CREDENTIAL }\end{array}$ & \\
\hline
\end{tabular}

- Situation of reading a letter

- $\quad$ "help", "escape" are lexical signals for the solution to the problem.

DETAILING - Landmine accident after the CAUSE bombing (cause)

- Ula lost both legs (problem)

- Little else to read

- $\quad$ Forget about misery

\begin{tabular}{|c|c|}
\hline $\begin{array}{l}\text { Soliciting } r \text { a } \\
\text { RESPONSE } \text { from } \\
\text { readers }\end{array}$ & $\begin{array}{l}\text { - Victims like Ula need help. } \\
\text { - Categories of "Help" } \\
\text { mentioned }\end{array}$ \\
\hline \multirow[t]{4}{*}{$\begin{array}{l}\text { VALUE OF THE } \\
\text { SUPPORT }\end{array}$} & $\begin{array}{l}\text { - } \quad \text { "Reunited with families" } \\
\text { - } \quad \text { future tense - "will be" }\end{array}$ \\
\hline & $\begin{array}{l}\text { - } \quad \text { has repaired school buildings } \\
\text { - } \quad \text { past perfect tense }\end{array}$ \\
\hline & $\begin{array}{l}\text { - } \quad \text { has delivered medical supplies } \\
\text { - } \quad \text { past perfect tense }\end{array}$ \\
\hline & $\begin{array}{l}\text { - has provided counseling to child } \\
\text { casualties } \\
\text { - past perfect tense }\end{array}$ \\
\hline
\end{tabular}




\begin{tabular}{|c|c|c|c|}
\hline Segment & TEXT & FUNCTION & EXPLANATION \\
\hline Seg. 1 & $\begin{array}{l}\underline{\text { Education now }} \\
\text { BREAK THE CYCLE OF } \\
\underline{\text { POVERTY }}\end{array}$ & Headline & - Main theme \\
\hline Seg. 2 & September xxxx & Date & - $\quad$ Crucial to the reality of the letter \\
\hline Seg. 3 & Dear Friend, & Salutation & $\begin{array}{l}\text { - } \text { Crucial to the reality of the letter } \\
\text { - } \quad \text { Personal touch with the reader }\end{array}$ \\
\hline Seg. 4 & $\begin{array}{l}\text { Oxfam is glad you can read this } \\
\text { letter }\end{array}$ & $\begin{array}{l}\text { EXPRESSING } \\
\text { GRATITUDE }\end{array}$ & $\begin{array}{l}\text { - } \quad \begin{array}{l}\text { Relational open (between "Dear Friend" } \\
\text { and "you" in segs. } 3 \text { and 4) }\end{array} \\
\text { - Involvement with reader }\end{array}$ \\
\hline Seg. 5 & $\begin{array}{l}\text { We are also grateful to be able } \\
\text { to write it. }\end{array}$ & & $\begin{array}{l}\text { - In seg. } 6 \text {, "But" is a word to show the } \\
\text { clause relation of "contrast" with the }\end{array}$ \\
\hline Seg. 6 & $\begin{array}{l}\text { But there are } 872 \text { million } \\
\text { adults and } 275 \text { million } \\
\text { children who can't read or } \\
\underline{\text { write. }}\end{array}$ & $\begin{array}{l}\text { INTRODUCING } \\
\text { THE CAUSE }\end{array}$ & previous sentence \\
\hline Seg. 7 & $\begin{array}{l}\text { Most of these illiterate people } \\
\text { are poor, very poor. }\end{array}$ & & - Illiterate people are poor, very poor \\
\hline Seg. 8 & $\begin{array}{l}\text { An education is the most } \\
\text { important thing to help people } \\
\text { GET OUT OF POVERTY. }\end{array}$ & $\begin{array}{l}\text { DETAILING } \\
\text { CAUSE AND }\end{array}$ & $\begin{array}{l}\text { - "help", "get out of " are lexical signals } \\
\text { for the solution to the problem. }\end{array}$ \\
\hline Seg. 9 & $\begin{array}{l}\text { Education is more than being } \\
\text { able to read and write. }\end{array}$ & $\begin{array}{l}\text { VALUE OF THE } \\
\text { SUPPORT }\end{array}$ & $\begin{array}{l}\text { - } \\
\text { read and write. } \\
\text { In seg } 8 \text {, it states about "education" is } \\
\text { important to get out of poverty. In seg } 9 \text {, } \\
\text { it is a basis to elaborate more about } \\
\text { education in segs. } 10,11,12 \text {. }\end{array}$ \\
\hline Seg. 10 & $\begin{array}{l}\text { It's about making a LIVING - } \\
\text { students learn skills to last a } \\
\text { lifetime }\end{array}$ & & $\begin{array}{l}\text { - Cohere to seg.9, (education)it's about } \\
\text { making a LIVING }\end{array}$ \\
\hline Seg. 11 & $\begin{array}{l}\text { It's also about HEALTH - for } \\
\text { parents to know when children } \\
\text { need a doctor. }\end{array}$ & & $\begin{array}{l}\text { - Cohere to seg.9, (education)it's also } \\
\text { about HEALTH }\end{array}$ \\
\hline Seg. 12 & $\begin{array}{l}\text { It's about poor people } \\
\text { protecting the few things they } \\
\text { might have, and getting the } \\
\text { things they deserve, by } \\
\text { knowing the LAW. }\end{array}$ & & $\begin{array}{l}\text { Cohere to seg.9, (education) it's about } \\
\text { poor people protecting the few things } \\
\text { they might have... by knowing the LAW. }\end{array}$ \\
\hline Seg. 13 & $\begin{array}{l}\text { In } 1990,155 \text { governments } \\
\text { agreed that a basic education is } \\
\text { "all the knowledge and skills } \\
\text { which people need if they are to } \\
\text { lead to a decent life." }\end{array}$ & $\begin{array}{l}\text { DETAILING } \\
\text { CAUSE }\end{array}$ & $\begin{array}{l}\text { It states that a basic education is "all the } \\
\text { knowledge and skills which people } \\
\text { need... } \\
\text { - (general truth, present tense) }\end{array}$ \\
\hline Seg. 14 & What is Oxfam doing? & $\begin{array}{l}\text { Question-answer } \\
\text { approach }\end{array}$ & $\begin{array}{l}\text { - "Speech act - Conversation approach" } \\
\text { is shown between segs. 14, 15, 16, } 17 \text { and } \\
18 .\end{array}$ \\
\hline Seg. 15 & $\begin{array}{l}\text { The following stories are just a } \\
\text { few of our projects in poor } \\
\text { countries. }\end{array}$ & $\begin{array}{l}\text { VALUE THE } \\
\text { SUPPORT }\end{array}$ & $\begin{array}{l}\text { - } \quad \text { improve education policy } \\
\text { - } \quad \text { verb indicating change of state }\end{array}$ \\
\hline Seg. 16 & $\begin{array}{l}\text { We also work to improve } \\
\text { education policy, as after all, it } \\
\text { is the government that has the } \\
\text { responsibility to provide a } \\
\text { basic, education for their } \\
\text { citizens. }\end{array}$ & & \\
\hline
\end{tabular}




\begin{tabular}{|c|c|c|c|}
\hline \multicolumn{3}{|c|}{ IJALEL 5(5):15-23, 2016} & \multirow{2}{*}{$\begin{array}{l}\text { 11 Oxfams around the world lobby for } \\
\text { debt relief so poor countries can have } \\
\text { more money to spend on school systems. }\end{array}$} \\
\hline Seg. 17 & $\begin{array}{l}\text { The } 11 \text { Oxfams around the } \\
\text { world lobby for debt relief so } \\
\text { poor countries can have more } \\
\text { money to spend on school } \\
\text { systems. }\end{array}$ & & \\
\hline Seg. 18 & $\begin{array}{l}\text { And we also work to educate } \\
\text { the Hong Kong public, } \\
\text { especially youth, on poverty - } \\
\text { why it happens and what can be } \\
\text { done. }\end{array}$ & $\begin{array}{l}\text { VALUE THE } \\
\text { SUPPORT }\end{array}$ & $\begin{array}{l}\text { - work to educate the Hong Kong public } \\
\text { - future solution }\end{array}$ \\
\hline Seg. 19 & $\begin{array}{l}\text { Visit the web site } \\
\text { Www.oxfam.org/educationnow } \\
\text { for more information. }\end{array}$ & $\begin{array}{l}\text { Soliciting the } \\
\text { RESPONSE from } \\
\text { the reader }\end{array}$ & $\begin{array}{l}\text { - Get more information about the } \\
\text { organisation }\end{array}$ \\
\hline Seg. 20 & What can YOU do? & \multirow{2}{*}{$\begin{array}{l}\text { Question-answer } \\
\text { approach }\end{array}$} & \multirow{3}{*}{$\begin{array}{l}\text { - "Speech act - Conversation approach" } \\
\text { is shown between segment } 14 \text { and the } \\
\text { following segments. }\end{array}$} \\
\hline Seg. 21 & $\begin{array}{l}\text { The best thing to do is be an } \\
\text { Oxfam Partner. }\end{array}$ & & \\
\hline & & $\begin{array}{l}\text { Soliciting } \\
\text { RESPONSE from } \\
\text { the readers }\end{array}$ & \\
\hline Seg. 22 & $\begin{array}{l}\text { Please donate what you can } \\
\text { every month. }\end{array}$ & \multirow{3}{*}{$\begin{array}{l}\text { Imperative Clause } \\
\text { Soliciting } \\
\text { RESPONSE from } \\
\text { the readers }\end{array}$} & \multirow{3}{*}{$\begin{array}{l}\text { - Reasons - "helps ensure that our projects } \\
\text { get the funding they need" in segs. } 23 \text { and } \\
24 \text { are given as prior to the imperative } \\
\text { clause in seg. } 22 \text {. }\end{array}$} \\
\hline Seg. 23 & $\begin{array}{l}\text { Your regular support helps } \\
\text { ensure that our projects get the } \\
\text { funding they need. }\end{array}$ & & \\
\hline Seg. 24 & $\begin{array}{l}\text { It also reduces administrative } \\
\text { costs. }\end{array}$ & & \\
\hline Seg. 25 & $\begin{array}{l}\text { You can also join our basic } \\
\text { education campaign or } \\
\text { volunteer (see the last page). }\end{array}$ & $\begin{array}{l}\text { Soliciting the } \\
\text { RESPONSE from } \\
\text { readers }\end{array}$ & $\begin{array}{l}\text { - Soliciting response from reader to be a } \\
\text { volunteer }\end{array}$ \\
\hline Seg. 26 & $\begin{array}{l}\text { Thank you for your joining our } \\
\text { work AGAINST poverty and } \\
\text { FOR education. }\end{array}$ & $\begin{array}{l}\text { EXPRESSING } \\
\text { GRATITUDE }\end{array}$ & - Involve reader at the closing of the letter \\
\hline Seg. 27 & (handwritten signature) & Signature & \multirow{4}{*}{$\begin{array}{l}\text { - Crucial to the reality of the letter } \\
\text { - "reality" - textual force (illocutionary } \\
\text { force) }\end{array}$} \\
\hline Seg. 28 & Lum Kwokchoi & Full Name & \\
\hline Seg. 29 & Education Coordinator & $\begin{array}{l}\text { Position (in the } \\
\text { organisation) }\end{array}$ & \\
\hline Seg. 30 & Oxfam Hong Kong & $\begin{array}{l}\text { ESTABLISHING } \\
\text { CREDENTIALS }\end{array}$ & \\
\hline Seg. 31 & $\underline{\text { P.S. Please support Oxfam. }}$ & $\begin{array}{l}\text { P.S. - Attention } \\
\text { getter }\end{array}$ & \multirow{2}{*}{$\begin{array}{l}\text { - P.S. is an attention getter. } \\
\text { - } \quad \text { "Reason - helping children get an } \\
\text { education ... get out of poverty" in seg. } \\
32 \text { is given as prior to the imperative } \\
\text { clause in seg. } 31 .\end{array}$} \\
\hline Seg. 32 & $\begin{array}{l}\text { You'll be helping children get } \\
\text { an education, and their } \\
\text { families get out of poverty. }\end{array}$ & $\begin{array}{l}\text { VALUE THE } \\
\text { SUPPORT }\end{array}$ & \\
\hline
\end{tabular}

\section{Findings and Discussion}

\subsection{Generalised move structure and sequence of the move}

Overall, we found that there are similar structural moves with promotional genre for those two appeal letters from two international non-profitable organisations. As stated in section 2 "Methodology", those two appeal letters collected are representative as pointed out by those two organisations, and the structural move includes (i) establishing credentials, (ii) introducing the cause, (iii) detailing the cause, (iv) value of the support, (v) enclosing donation forms, (vii) soliciting support and (viii) expressing gratitude. However, we found that the move of "offering incentive" is missing in both samples of appeal letters (sample texts 1 and 2). Probably, the move of offering incentive by stating "income tax rebate" could be found in some enclosed donation forms, not directly stated in the appeal letters. The following is a table listing the move structure of genre mixing of advertising and philanthropic discourse. 
Table 4. Structural Moves of those Two Sample Texts (Genre Mixing of Promotional and Philanthropic Discourse)

Segment TEXT 1

APPEAL LETTER- UNICEF

APPEAL LETTER- Oxfam

\begin{tabular}{|c|c|c|}
\hline Seg. 1 & - Date & - Headline \\
\hline Seg. 2 & - $\quad$ Salutation & - Date \\
\hline Seg. 3 & \multirow{2}{*}{$\begin{array}{l}\text { - GIMMICK - Marked device attention- } \\
\text { getter }\end{array}$} & - $\quad$ Salutation \\
\hline Seg. 4 & & - EXPRESSING GRATITUDE \\
\hline Seg. 5 & \multirow[t]{2}{*}{ - INTRODUCING THE CAUSE } & \\
\hline Seg. 6 & & - INTRODUCING THE CAUSE \\
\hline Seg. 7 & \multirow{3}{*}{$\begin{array}{ll}\text { - } & \begin{array}{l}\text { Marked device attention-maintaining } \\
\text { device }\end{array}\end{array}$} & \\
\hline Seg. 8 & & - DETAILING CAUSE AND \\
\hline Seg. 9 & & - VALUE OF THE SUPPORT \\
\hline Seg. 10 & \multirow[t]{4}{*}{ - INTRODUCING THE CAUSE } & \\
\hline Seg. 11 & & \\
\hline Seg. 12 & & \\
\hline Seg. 13 & & - DETAILING CAUSE \\
\hline Seg. 14 & \multirow{4}{*}{ - DETAILING THE CAUSE } & \multirow{5}{*}{$\begin{array}{ll}\text { - } & \text { Question-answer approach } \\
\text { - } & \text { VALUE THE SUPPORT }\end{array}$} \\
\hline Seg. 15 & & \\
\hline Seg. 16 & & \\
\hline Seg. 17 & & \\
\hline Seg. 18 & - $\quad$ Soliciting a RESPONSE from reader & \\
\hline Seg. 19 & \multirow[t]{4}{*}{ - VALUE OF THE SUPPORT } & $\begin{array}{l}\text { - Soliciting the RESPONSE from the } \\
\text { reader }\end{array}$ \\
\hline Seg. 20 & & \multirow{5}{*}{$\begin{array}{ll}\text { - } & \text { Question-answer Approach } \\
\text { - } & \text { RESPONSE } \\
\text { - } & \text { Imperative Clause } \\
\text { - } & \text { RESPONSE }\end{array}$} \\
\hline Seg. 21 & & \\
\hline Seg. 22 & & \\
\hline Seg. 23 & - ENCLOSING DONATING FORM & \\
\hline Seg. 24 & - $\quad$ Soliciting RESPONSE & \\
\hline Seg. 25 & - Complimentary Close & - $\quad$ Soliciting RESPONSE \\
\hline Seg. 26 & - $\quad$ Signature & - EXPRESSING GRATITUDE \\
\hline Seg. 27 & - ESTABLISHING CREDENTIAL & - $\quad$ Signature \\
\hline Seg. 28 & - $\quad$ Position (in the organisation) & - $\quad$ Full Name \\
\hline Seg. 29 & - ESTABLISHING CREDENTIAL & - $\quad$ Position (in the organisation) \\
\hline Seg. 30 & Nil & - ESTABLISHING CREDENTIAL \\
\hline Seg. 31 & Nil & $\begin{array}{ll}\text { - } & \text { P.S. - Attention getter } \\
\text { - } & \text { VALUE OF THE SUPPORT }\end{array}$ \\
\hline
\end{tabular}

As for the sequence of all moves from those two sample texts, it has revealed that the sequence of the structural moves varies. However, the move of "introducing the cause" is always stated at the beginning because the readers are interested in what the main theme mentioned in that particular text. Also, it is found that "establishing credential" is found at the end, as a "re-enforcer to the readers that the particular charity has a good reputation and the spending of their donation is properly distributed. As stated in section 2 "Promotional Genre vs Fund-raising Text", Bhatia (1998: 14) has highlighted the generic patterns in funding raising discourse, and he further argues that like most business promotional letters, fund raising letters also have a relatively simple move discourse structure. Based on those two sample texts collected in Hong Kong, the findings in this paper appear to be in line with Bhatia's (1998) argument, supporting that promotional concerns have also influenced the nature of philanthropic discourse. 
4.2 Rhetorical choices of promotion in appeal letters

\subsubsection{Marked devices of attention-getters}

In those two fund-raising appeal letters, there were some rhetorical choices of promotion which aim at getting "special" attention from readers. For the sample text 1, it is found that there is a promotional marked device which is just like an "advertising tool" of raising the attention from readers. The following segments 3 and 4 aim to attract the attention of readers by "asking" readers not to read the appeal letter, by contrast, aim at stimulating the readers' curiosity to see what the main theme of the fund-raising appeal letter is.

segment $3 \quad$ Can you stop reading and think about something else?

segment $4 \quad$ This is a letter about children in war, so stop reading and switch your attention to something more pleasurable, such as what you'll have for dinner, or what's on the television tonight.

Quoted from the seventh and eighth segments of the text as another illustration:

segment $7 \quad$ Are you still with me?

segment $8 \quad$ Good, because statistically speaking about $30 \%$ of readers normally would have stopped by the time they read that fact.

The segments 7 and 8 are also promotional attention devices which aim to "maintain the attention" of readers by "crosschecking" readers if they are still there to read the message.

4.2.2 Involvement of readers - Using "you"

According to Smith (1996: 113), "“you" is the word that used most frequently in the fundraising letters". True or not, it is indeed used very frequently. Tannen $(1989 ; 2005)$ also highlights that the use of the words "you" and "I" is critical as they provide human interest. She (1898: 27) clearly points out that "Stories, anecdotes, and common names have some of the same effect - but the most powerful way to engage the reader is by appealing directly to her: use the word "you". That is an involvement device which is aimed to make the reader particular, which increases the possibility to solicit response successfully."

Examples:

Text 1:

Seg.

3 Can you stop reading and think about something else?

4 so stop reading and switch your attention to something more pleasurable, such as what you'll have for dinner...

$7 \quad$ Are you still with me?

25 Yours sincerely

Text 2:

Seg.

$4 \quad$ Oxfam is glad you can read this letter.

20 What can $\mathbf{Y O U}$ do?

26 Thank you for your joining our work AGAINST poverty and FOR education.

32 You'll be helping children get an education, and their families get out of poverty.

As can be seen from the sample appeal letters 1 and 2, it is known to everybody that letters are meant to establish a dialogue with a "you". While the pronoun "you" appears in various positions in the textual structure, the letters show it in those steps where the anticipated success of the reader's donation (response) is described, e.g. "you can help 4 women to build energy-saving stoves..." It seems that here the textual structure works together with style in some multiple functions. The use of "you" in the letter format has some relational closing (quoted in Bhatia 1993: 55) which aims at establishing good "business relations", and maybe some emotional satisfaction.

Relational closing is to add involvement with readers at the end of text by using an involvement device. "You" is an involvement device, and the "relational closing of you" functions to increase response from readers by being a reminder and also adding more involvement with readers in the text. That is the reason of why "soliciting response or support" is always found near the closing of the appeal letters. All examples showing the relational closing of "you" are listed as follows: 
Examples:

Text 1:

Segment

24 You've come this far, all we ask of you now is to put aside a minute to fill in the donation form and change the life of a child.

25 Yours sincerely (Complimentary close)

Text 2:

Segment

26 Thank you for your joining our work AGAINST poverty and FOR education.

32 You'll be helping children get an education, and their families get out of poverty. (the last sentence)

To conclude, by using "you - an involvement device" in appeal letters, it is meant to add more involvement with readers and then solicit responses from them. In addition, assuming that the writer and the reader have the same or very similar beliefs and values, the appeal letters set out to influence conduct in a very specific way - "relational closing"; that is, to get responses from readers to send in a contribution.

\section{Conclusion}

Based on those two appeal letters in Hong Kong, the findings appear to reveal that there is a hybrid form of promotional genre in philanthropic discourse, according to Bhatia's (1998) generic patterns in fund-raising discourse framework. There are similar structural moves of advertising, although the move sequences could vary according to different texts. However, the move of 'introducing the cause' is always found at the very beginning because readers are more interested to realise what the main theme of the appeal letter is. In addition, appeal letters are found to be modelled in promotional genre, in which they are promotional strategies of attracting attention from readers - using "you" and marked devices of attention getters. The findings in this study appear to be in line with the argument that promotional concerns have influenced the nature of philanthropic discourse. Finally, the data collection is limited to only two appeal letters from two organisations; however, this study can be treated as an exploratory one to investigate how the appeal letters can be modelled in promotional genre.

\section{References}

Bhatia, V. K. (1993). Analysing genre: language use in professional settings. London: Longman.

Bhatia, V. K., (1997). Genre-mixing in academic introductions, English for Specific Purposes, 16, 3, 181-196.

Bhatia, V. K. (1998). Generic patterns in fundraising discourse, New Directions for Philanthropic Fundraising. 22, 95110.

Bhatia, V.K. (2004). Worlds of written discourse: A genre-based view, London and New York: Continuum.

Bhatia, V.K. (2008). Genre analysis, ESP and professional practice', English for Specific Purposes 27, 161-74.

Bhatia, V.K. (2010). Interdiscursivity in professional communication', Discourse and Communication, 4/1, 32-50.

Clarke, S. \& Norton, M. (1997). The complete fundraising handbook. London: Directory of social change.

Fairclough, N. (1993). Critical discourse analysis and the marketisation of public discourse: The universities. Discourse and Society. 4 (2): 133-68.

Featherstone, M. (2007). Consumer culture and postmodernism. London: Sage.

Mann, W. \& Thompson, S. (1992). Discourse description: Diverse linguistic analyses of a fund-raising text. Amsterdam: John Benjamins Publishing Company.

Rotzoll, K. B., Haefner, J. E., \& Sandage, C. H. (1986). Advertising in contemporary society. West Chicago, IL: SouthWestern Publishing Company.

Smith, G. (1996). Asking properly: The art of creative metaphor. San Diego: Academic Press.

Tannen, D. (1989). Talking voices: Repetition, dialogue and imagery in conversational discourse. New York: Cambridge University Press

Tannen, D. (2005). Conversational style: Analyzing talk among friends. New York: Oxford University Press.

Weinstein, S. (2009). The complete guide to fundraising management. N.J.: John Wiley \& Sons.

Wharton, C. (2015). Advertising: Critical approaches. Abingdon, Oxon: Routledge. 